\title{
How to deal with low-flow low-gradient aortic stenosis and reduced left ventricle ejection fraction: from literature review to tips for clinical practice
}

\author{
F. Contorni ${ }^{1}$ (D) M. Fineschi ${ }^{1} \cdot$ A. Iadanza ${ }^{1} \cdot$ A. Santoro ${ }^{1} \cdot$ G. E. Mandoli ${ }^{1} \cdot$ M. Cameli $^{1}$
}

Accepted: 15 February 2021 / Published online: 8 March 2021

(c) The Author(s) 2021

\begin{abstract}
Low-flow low-gradient aortic stenosis (LFLG AS) with reduced left ventricle ejection fraction (LVEF) is still a diagnostic and therapeutic challenge. The aim of this paper is to review the latest evidences about the assessment of the valvular disease, usually difficult because of the low-flow status, and the therapeutic options. Special emphasis is given to the available diagnostic tools for the characterization of LFLG AS without functional reserve at stress echocardiography and to the factors that clinicians should evaluate to choose between surgical aortic valve repair, transcatheter aortic valve implantation, or medical therapy.
\end{abstract}

Keywords Low-flow low-gradient aortic stenosis · TAVI in low-flow low-gradient aortic stenosis - TAVI in bicuspid aortic valve $\cdot$ After TAVI paravalvular leak $\cdot$ After TAVI permanent pacemaker implantation $\cdot$ SAVR vs TAVI

\section{Introduction}

Low-flow low-gradient aortic stenosis (LFLG AS) is an echocardiographic entity defined by a mismatch between a reduced aortic valve area (AVA, $<1 \mathrm{~cm}^{2}$ ) and a non-severe increase of transvalvular mean pressure gradient (MPG, $<40 \mathrm{mmHg}$ ) with an impaired stroke volume at rest (SV index $\leq 35 \mathrm{ml} / \mathrm{m}^{2}$ ) [1,2]. LFLG AS still puts the clinicians in front of diagnostic and therapeutic dilemmas: making a correct diagnosis and choosing between an aortic valve replacement (AVR) on top of medical therapy vs an optimal medical therapy (OMT) alone. The choice passes through the balance between a key selection of those patients who can really benefit from AVR and the intrinsic risk related to the procedure. Finally, when AVR is the chosen treatment, surgical AVR (SAVR) and transcatheter aortic valve implantation (TAVI) are both available options. The aim of this paper is to review the latest evidences about the optimal diagnostic workup and management of LFLG AS with reduced left ventricle ejection fraction $(\mathrm{LVEF}<50 \%)$.

This paper has not been previously reported.

F. Contorni

francescocontorni01@gmail.com

1 Department of Medical Biotechnologies, Division of Cardiology, University of Siena, Siena, Italy

\section{Severity assessment}

Identifying the patients who might benefit from a valvular prosthesis rather than from OMT alone is a crucial step in the management of left heart valvular diseases. The main point is the identification of the right timing for intervention: not too early, to avoid the unnecessary exposition to procedural risks, but not too late, when heart could already be irreversibly damaged. According to the latest guidelines [1, 2], the assessment of a severe AS is the sine qua non to take AVR into consideration. While a suspected AS in the context of a normal flow status (classically defined by a normal stroke volume) can be defined as severe by echocardiography at rest $\left(\mathrm{AVA}<1 \mathrm{~cm}^{2}\right.$ and MPG $>40 \mathrm{mmHg}$ ), LFLG AS needs further diagnostic exams.

\section{Echocardiography}

The combination of a LVEF $<50 \%$, an AVA $<1 \mathrm{~cm}^{2}$, and an MPG $<40 \mathrm{mmHg}$ can be explained by an underlying impaired left ventricle, unable to generate a sufficient SV for a complete AV opening, and potentially, a severe transvalvular gradient. Rest hemodynamic conditions do not provide a reliable evaluation of true AV performance when EF is reduced, so the actual guidelines [1,2] recommend to perform a low-dose dobutamine stress echocardiography 
exam (DSE) to induce an SV increase and contemporarily analyze the AV adaptation. DSE can give three possible results:

- Significant increase in SV $(\Delta \mathrm{SV} \geq 20 \%)$ and persistent low MPG (MPG $<40 \mathrm{mmHg}$ ): pseudo-severe $A S$. In this case, the LV contractile dysfunction outweighs AS inside heart failure (HF) pathophysiology. AS does not meet the hemodynamic criteria to be defined as severe.

- Significant increase in SV $(\triangle \mathrm{SV} \geq 20 \%)$ and in MPG (MPG > $40 \mathrm{mmHg}$ ): true severe $L F L G$ AS. Aortic valve is severely stenotic and the low gradient measured at rest is a consequence of the $\mathrm{LV}$ contractile dysfunction.

- Absence of significant increase in SV $(\triangle \mathrm{SV}<20 \%)$ and MPG (MPG $<40 \mathrm{mmHg}$ ): LFLG AS without functional reserve $(F R)$. In this case, DSE fails to demonstrate an AV hemodynamic adaptation to higher SV and the AS severity grade remains undetermined.

According to the current guidelines [1,2], if DSE does not demonstrate a FR, the actual degree of stenosis cannot be assessed by dynamic echocardiographic parameters and clinicians have to rely on the morphologic features of the AV showed by cardiac computed tomography (CCT). In the following section, we describe the emerging role of two flow rate-based echocardiographic tools, although not already included in the diagnostic workup recommended by ESC and AHA.

\section{Echocardiography beyond functional reserve: the emerging role of the flow rate over the stroke volume}

In recent years, new echocardiographic tools have been studied to overcome the diagnostic limitation of the ultrasound in the context of LFLG AS. In 2006, a large multicenter observational study on LFLG AS developed and validated a new echocardiographic tool to obtain reliable information about the severity of AS, even without FR at DSE: the projected aortic valve area (AVAProj) [3]. This parameter is intended to predict the value that AVA would reach at a normalized flow rate of $250 \mathrm{ml} / \mathrm{s}$, basing on the AVA adaptations recorded during DSE at different flow ratio. AVAProj quantification assumes that, despite that DSE does not show a significant FR, the dobutamine infusion determines an increase of SV, although small. The assessment of AVA by the continuity equation at different flow ratios allows to estimate the so-called "valve compliance" (VC) and, as a result, the AVA in case of a normal SV. The original equation for AVAproj was
AVAproj $=$ AVArest + VC $\times(250-$ Qrest $)$

where AVArest is aortic valve area at rest and Qrest is transaortic flow rate measured at rest.

Recently, a simpler and less time-consuming equation has been validated [4]:

AVAproj $=$ AVArest $+(\triangle$ AVA $/ \triangle \mathrm{Q}) \times(250-$ Qrest $)$

where $\triangle \mathrm{AVA}$ is the difference between aortic valve area calculated by continuity equation at peak DSE and rest and $\Delta \mathrm{Q}$ the difference between transaortic flow rate measured at peak DSE and rest.

In the latter formula, only basal left ventricle outflow tract (LVOT) diameter, LVOT velocity-time integral (VTI), AVA VTI at baseline and at DSE peak are needed to quantify the AVAproj. The reliability of this parameter has been recently confirmed by an update of the True or Pseudo Severe Aortic Stenosis (TOPAS) study [5] where AVAProj had a better diagnostic accuracy than MPG and AVA at peak DSE in detecting a severe AS: an AVAproj $\leq 1 \mathrm{~cm}^{2}$ showed a diagnostic accuracy (percentage of correct classification) of $70 \%$ in predicting severity while an aortic MPG $\geq 40 \mathrm{mmHg}$ alone or combined with peak AVA $\leq 1 \mathrm{cmq}$ of $48 \%$ and $47 \%$ only, respectively.

Thus, AVAproj is a promising tool to optimize the achievable data with DSE and brought to analyze the diagnostic predicting value of transaortic flow rate (FLR) at rest. Transaortic flow rate is defined as

FLR $=$ SV $/$ LVET

where LVET is the left ventricle ejection time, measured as the time interval between the beginning point and the end point of the LVOT VTI. Conceptually, FLR is a measure of flow (volume unit per unit of time) as well as stroke volume; nevertheless, the stroke volume measures the transaortic flow during a single cardiac beat (including both systole and diastole), while FLR measures only the effective blood volume ejected during the systolic phase. In a setting of low flow $(\mathrm{SVi}<35 \mathrm{ml})$, FLR can be normal or reduced as a consequence to a short or long ejection time, respectively. A pioneering study showed that in a setting of low SV, a normal FLR at rest could be a good predictor of true severe AS because AVA will likely not increase during DSE; at the contrary, when the rest FLR is $<200 \mathrm{ml}$, DSE can be truly useful to unmask a pseudo-severe LFLG AS [6].

\section{Cardiac computed tomography}

There is an extensive body of research showing CCT as a reliable test to detect severe AS. CCT calcium score shows a linear correlation with echocardiographic and cardiac 
catheterization parameters $[7,8]$ indicative of severe AS and with surgical visual assessment of the valve [9]. On these bases, CCT should be able to overcome the diagnostic limitation in the setting of LFLG AS without FR and to give a static, morphological severity score. Calcium score cut-off values for severe AS have been validated on normal flownormal gradient AS according to the different degrees of AS. Two different studies $[8,10]$ successively confirmed the need for different gender cuf-off values (men $>2000$ A.U., women $>1200$ A.U.). A total of 794 patients with different degree of AS at echocardiography underwent a CCT and were followed up for all-cause death in a large observational study [11]. Severe AV calcification (defined by 1180 A.U. in women and 2050 A.U. in men) was an independent and significant predictor of mortality ( $p 0.001)$, confirming the diagnostic accuracy of CCT.

\section{Other imaging techniques}

Transesophageal echocardiography (TOE) is a well-known and valid alternative to TTE to assess AV planimetry and provides a good visualization of LVOT. It has even been suggested that TOE could guarantee not only a more accurate planimetric valve area assessment than TTE but also a more reliable LVOT area calculation; consequently, a hybrid approach with TTE-derived VTI and TOEderived LVOT area would give a more precise estimation of true AVA by continuity equation [12]. Also, the invasive measurements of left ventricle and aortic pressures can give a functional AVA estimation by the Gorlin equation or by the Hakki's simplified version of the formula, during left heart catheterization. Finally, planimetric and continuity equationderived AVA obtained by cardiac magnetic resonance (CMR) showed good correlation with TTE and TOE [13]. All these quantification techniques can be useful in the case of poor acoustic window or inadequate Doppler alignment, but none of them is able to give a comprehensive assessment of AS severity grade in the low-flow setting.

How previously observed, a LFLG AS, especially without FR at DSE, gives rise to questions about the amount of LVEF impairment that could be attributed to the AS itself or to other causes. From this point of view, the myocardial tissue characterization provided by CMR can add useful information to understand the nature of LV dysfunction; AS is often associated to late gadolinium enhancement (LGE), usually with a midwall scar, differently from the typical pattern of myocardial infarction. Moreover, the presence of midwall LGE in AS has been associated to a significantly higher rate of 30-day mortality [13]. Although the current guidelines for heart valve disease management $[1,2]$ do not recognize a role to CMR in the diagnostic workup of AS, this technique might provide adjunctive data to predict the possible benefits of AVR.

\section{Choosing between invasive and conservative treatment}

The diagnosis of severe AS according to the previously described multimodality criteria (irrespective to flow status and LVEF) is essential to take AVR into consideration. The replacement of a non-severely stenotic aortic valve can be evaluated only with another concomitant indication for cardiac surgery $[1,2]$. Nevertheless, in the context of reduced LVEF, even those patients with moderate AS could expect a significant prognostic improvement with AVR vs OMT $[14,15]$. At this regard, the TAVR-UNLOAD [16] is an ongoing clinical trial that is expecting to clarify the need for an eventual redefinition of the criteria to establish the need for AVR in the setting of impaired LVEF. To date, the diagnosis of true severe LFLG-AS is currently mandatory to discuss an eventual AVR and pseudo-severe LFLG AS should be treated with conventional heart failure medications.

Once the severity of LFLG AS has been confirmed, the benefit/risk ratio of the patient must be taken into account to justify an intervention. First of all, all the available studies agreed on a poor long-term survival when LFLG AS is treated with OMT alone [17-21] (Table 1). On the other hand, the coexistence of severe AS and impaired LVEF determines a not-negligible perioperative mortality risk [18, 19, 21-24] (Table 2). SAVR is still associated with a high short-term risk of death in LFLG AS, even though recent advancements in both surgical and anesthesiologic techniques determined a significant improvement. A large observational study [23] which enrolled 217 cases of LFLG AS between 1990 and 2005 showed an overall mortality of $16 \%$ during the first 30 postoperative days, however with a notable reduction in the last decades (20\% in the 1990-1999 period, mean Euroscore $8.9 \%$ vs $10 \%$ since 2000, mean Euroscore 9.2\%). According to this study, a NYHA class III or IV, a high EUROSCORE (perioperative mortality of $25 \%$ with an EUROSCORE $>10 \%$ ), an $\mathrm{MPG}<20 \mathrm{mmHg}$, a concomitant multivessel CAD, and the absence of FR at DSE were the major predictors of mortality $(p<0.01)$. The coexistence of an unquestionable prognostic improvement after AVR and a high risk of death linked to an absent FR at DSE finds a match in the current guidelines [1,2], where there is a strong recommendation for AVR in LFLG AS with FR (class of recommendation I, level of evidence C and I,B, respectively) and a more cautious approach in case of no FR (IIa,C according to ESC, while AHA guidelines do not provide a clear indication). Nevertheless, the mentioned studies considered only SAVR but a lower 30-day mortality rate could be expected with the less invasive TAVI. Among the major RCTs that compared TAVI vs SAVR, only the PARTNER 1 made a sub-analysis on severe LFLG AS patients showing only a small increase of risk with SAVR 
Table 1 LFLG AS with reduced LVEF (EF $<50 \%)$ — comparison between AVR and OMT

\begin{tabular}{|c|c|c|c|}
\hline & $\begin{array}{l}\text { Population of interest (LFLG AS with reduced } \\
\text { LVEF) }\end{array}$ & Type of AVR & AVR vs OMT HR for death at long-term follow-up \\
\hline Sato et al. $[17]^{\mathrm{a}}$ & 86 & TAVI and SAVR & HR $0.32[6,6] p<0,001$ \\
\hline Tribouilloy et al. [18] & 81 & SAVR & $\begin{array}{l}\text { HR } 0.16 \text { to } 5.21 \text { varying with time } \\
{[0.12-3.16 \text { to } 0.21-8.50], p<0.00026^{\text {b }}}\end{array}$ \\
\hline Monin et al. [19] & $136 \mathrm{pt}$ & SAVR & HR $0.3(p 0,001)$ \\
\hline Herrmann et al. [20] & $\begin{array}{l}42 \mathrm{pt} \text { (considering only inoperable true severe } \\
\text { LFLG AS with low EF, cohort B) }\end{array}$ & TAVI & HR $0.43 ; 95 \%$ CI [0.19-0.98] P=0.04 \\
\hline Clavel et al. [21] & $101 \mathrm{pt}$ & TAVI and SAVR & HR 0.57 [ 0.40 to 0.82 ] $\mathrm{P}=0.02$ \\
\hline
\end{tabular}

${ }^{a}$ Only considering true LFLG AS

${ }^{b}$ Hazard ratio has been obtained with a single-variable Gray model instead of classical Cox model. This statistical approach allows the regression coefficients to change over different time intervals, taking into account the drop of HR for death after perioperative period

in comparison with TAVI [20]. This result can be partially dampened by the exclusion of LFLG-AS without FR from the study population. Magner et al. [24] enrolled 225 patients diagnosed with LFLG AS and impaired LVEF, with or without FR; all the patients underwent TAVI and 30-day mortality was $8.9 \%$, slightly higher than those calculated by preoperative surgical risk score (mean STS 7.6\%). Of note, the enrolment period was 2006-2014, including the very early stage of TAVI use so the not negligible perioperative mortality rate could be now partially mitigated by progressive increase of expertise and technical improvements in the field of structural interventional cardiology. At this regard, Ribeiro and colleagues [22] enrolled, from 2013 to 2017, a cohort of patients who underwent TAVI for LFLG AS and impaired LVEF, having high average preoperative surgical risk (mean STS score $7.7 \%$, mean EUROSCORE II 10.5\%). The 30-day mortality rate was $3.8 \%$, notably lower than the preoperative risk estimation. In any case, TAVI in LFLG AS with impaired LVEF seems to be associated to a significant higher mortality in comparison with classical AS: in a recent large matched cohort observational study [25], 1-year mortality after percutaneous AVR in LFLG AS with $\mathrm{EF}<50 \%$ was more than double than in high gradient severe AS.
Moreover, the prognostic role of FR at DSE has been recently questioned by several works $[5,13,26,27]$ and new proposed echocardiographic flow rate-based tools seem to provide a better risk estimation than the classic SVi increasement during dobutamine infusion. In the previous mentioned TOPAS-TAVI study [22], the patients underwent DSE (44\% LFLG AS with FR, 56\% LFLG AS without FR) before TAVI and FR were actually not correlated to the 2-year cardiovascular mortality $(p=0.38)$. Sato et al. [17] followed up 235 patients with LFLG AS and reduced LVEF for a median follow-up of 2.3 years (including, according to DSE results, pseudo-severe AS, true severe AS, and indeterminate AS). AVR (SAVR and TAVI) was performed in 128 patients and the study failed to demonstrate any significant survival difference between patient with or without FR treated with OMT vs AVR; on the contrary, an AVAproj $<1 \mathrm{~cm}^{2}$ well predicted the outcome: the patients with an AVAproj $<1 \mathrm{~cm}^{2}$ treated with AVR had a significant higher survival than those medically treated. Similarly, in a cohort of 218 patients with resting low gradient AS (resting MPG $<40 \mathrm{mmHg}$ and $\mathrm{AVA}<1 \mathrm{~cm}^{2}$ ) undergoing AVR, a low FLR at rest was an independent predictor of the medium-term mortality [27], while absent FR was not.

Table 230 days any cause mortality after AVR in LFLG AS with impaired LVEF $(\mathrm{EF}<50 \%)$

\begin{tabular}{|c|c|c|c|c|c|}
\hline & $\begin{array}{l}\text { Population of interest } \\
\text { (LFLG AS with reduced } \\
\text { LVEF) }\end{array}$ & Type of AVR & Surgical risk estimation & 30-day mortality & 30-day mortality risk factors \\
\hline Ribeiro et al. [22] & 287 & TAVI & STS $7.7 \%$ & $3.8 \%$ & $\begin{array}{l}\text { COPD } p 0.022 \\
\text { Anemia } p 0.004\end{array}$ \\
\hline Tribouilloy et al. [18] & 81 & SAVR & - & $22 \%$ & $\begin{array}{l}\text { Associated CABG }(p \text { 0.007) } \\
-\mathrm{MPG}<20 \mathrm{mmHg}(p 0.035)\end{array}$ \\
\hline Monin et al. [19] & 136 & SAVR & - & $14 \%$ & $\begin{array}{l}\text {-Lack of FR }(p 0.001) \\
-\mathrm{MPG}<20 \mathrm{mmHg}(p 0.04)\end{array}$ \\
\hline Clavel et al. [21] & 101 & TAVI and SAVR & - & $18 \%$ & - \\
\hline Levy et al. [23] & 217 & SAVR & Euroscore $8.9 \%$ & $16 \%$ & - \\
\hline Magner et al. [24] & 225 & TAVI & STS $7.6 \%$ & $8.9 \%$ & - \\
\hline
\end{tabular}


These results can possibly be explained by a superiority of these new parameters in the identification of patients with a true severe AS, so having a real expected benefit from AVR. The reliability of FR in demonstrating a myocardial damage and, consequently, a benefit from AVR, has also been challenged by CMR. Rosa et al. [28] enrolled 41 LFLG AS and 24 normal flow-high gradient AS, all undergoing CMR; the LFLG group underwent DSE to assess the FR, too. The LFLG AS group had more myocardial fibrosis (expressed by extracellular volume and LGE) than the control group, but among LFLG AS, a significant difference between patients with and without FR did not emerge.

Finally, although large trials comparing OMT, TAVI, and SAVR in LFLG AS are not available yet, OMT alone seems to be reserved to patients at very high perioperative risk and short life expectancy. At the same time, it is unquestionable that AVR in LFLG AS with reduced LVEF is affected by worst short- and long-term outcomes in respect to severe AS with preserved EF, irrespectively, to the adopted treatment strategy. Nevertheless, the absence of FR at DSE should not be considered the best predictor of a poor response to AVR, anymore. An accurate selection of patients should include all the other mentioned parameters (CCT calcium score, AVAproj, FLR) in addition to the standard ones with the aim to demonstrate a truly severe AS which will prognostically benefit from AVR (Fig. 1).

\section{Choosing between surgical and transcatheter AVR}

To date, there is not a defined algorithm to guide the choice between SAVR and TAVI, and the Heart Team specialists have to make each single case-tailored evaluation. When both the therapeutic options are available (anatomical feasibility criteria for TAVI go beyond the purpose of this paper), the main questions to face include long-term outcomes and assessment

\section{DIAGNOSTIC PATHWAY TO ASSESS AORTIC STENOSIS SEVERITY GRADE}

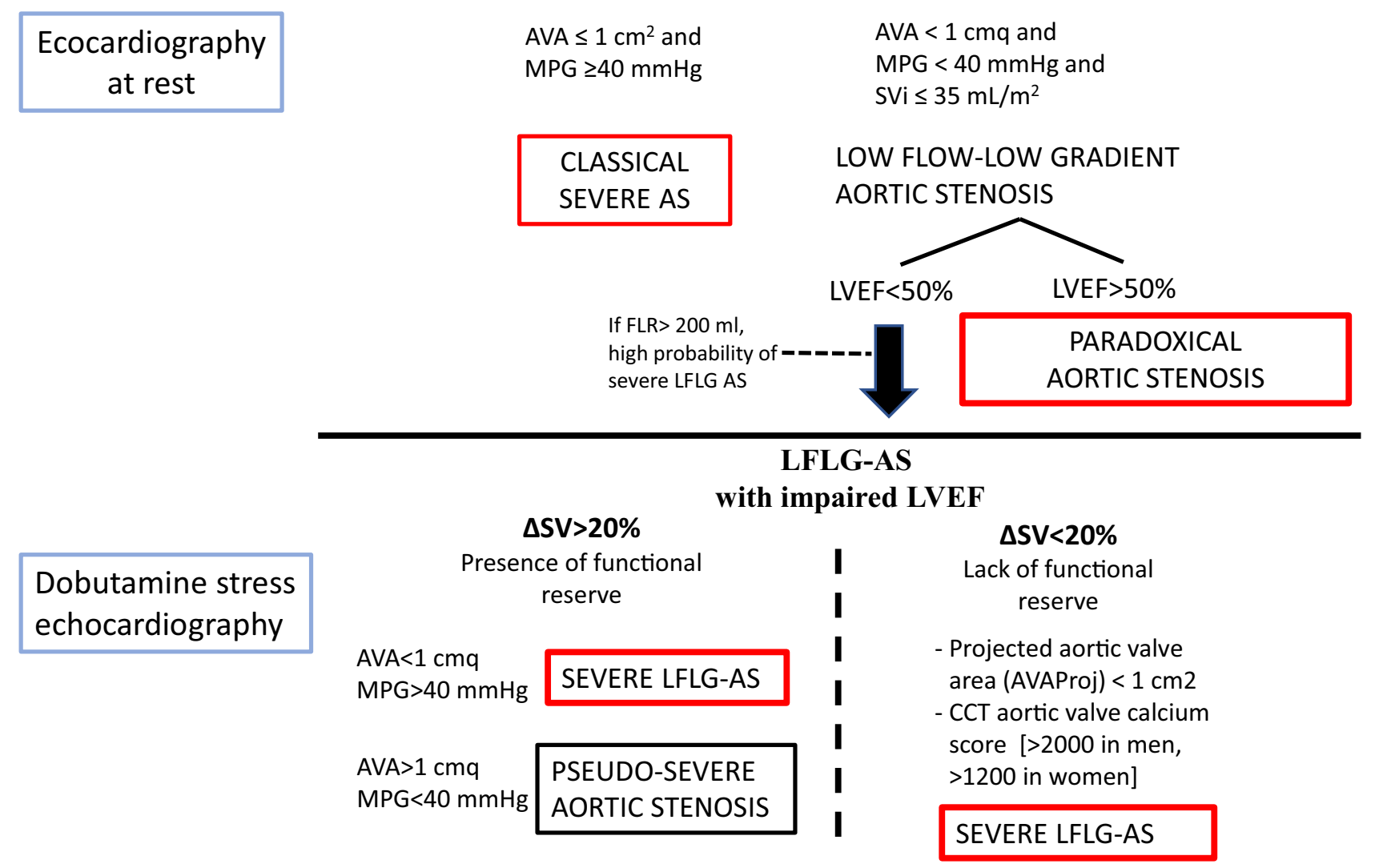

Fig. 1 Proposed diagnostic workup to assess the severity grade of lowflow low-gradient aortic stenosis, including the emerging flow rate-based echocardiographic tools (AVAproj and resting FLR). Abbreviations: AVA: aortic valve area; AVAproj: projected aortic valve area; CCT: cardiac computed tomography; FLR: transaortic flow rate at rest; MPG: trans-aortic mean pressure gradient; SVi: stroke volume index; $\Delta \mathrm{SV}$ : stroke volume variation between rest and stress 
of the risk factors for procedure-related complications. Specifically, in the setting of an already impaired LVEF, the risk of paravalvular leak (PVL) and conduction disturbances after TAVI deployment have to be carefully evaluated, because of their nonnegligible prognostic implications (Fig. 2).

\section{Perioperative risk vs long-term outcomes}

How previously observed, despite solid statistical evidences of perioperative risk reduction are still missing, TAVI is an attractive therapeutic option for LFLG AS, especially for patients at high surgical risk. Whether there could be a significant difference about long-term outcome is still an open question. Historically, the approval process for TAVI clinical use went through RCTs comparing the outcomes of patients with different surgical risk treated with TAVI vs SAVR. According to these studies [29-35], TAVI is not inferior for 1-year survival rate, regardless of surgical risk. Moreover, in high-risk and intermediate-to-high-risk patients, the transcatheter approach demonstrated a non-inferiority to SAVR at 2 and 5 years, too. The mentioned trials had a non-inferiority statistical design for a composite cardiovascular outcome (except for SURTAVI [32] which failed to show superiority of TAVI anyway). Nevertheless, a recent metaanalysis [36] including the 7 major RCTs comparing TAVI and SAVR outcomes concluded that TAVI, via transfemoral approach (known to be the safest one), was associated with the higher survival benefit on a 2-year follow-up (17\% of death risk reduction [HR 0.83 (95\% CI 0.72-0.94)), regardless of surgical risk. It should be observed that although the RCTs with the longer follow-up (5 years) showed a non-inferiority to SAVR, the survival benefit of the percutaneous approach vs surgery tended to decrease over time [29-35, 37-39] (Table 3). A small window on the behavior of TAVI after 5 years from implantation was provided by the UK TAVI register: among 241 patients, only $22(9.1 \%)$ had a moderateto-severe structural valve degeneration [40]; nevertheless, comparing this data with the one regarding surgical prostheses is difficult mostly because of the inhomogeneous criteria of valve degeneration adopted by literature. The concerns about TAVI longevity in low-risk patients with good life expectancy could be mitigated by the possibility to treat bioprosthetic degeneration with another transcatheter valve implantation.

\section{Management of severe LFLG AS with reduced left ventricle ejection fraction (LVEF<50\%)}

\section{AVR vs OMT}

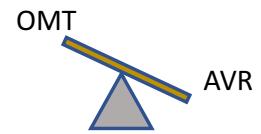

AVR gives significatively better long-term outcomes than OMT alone

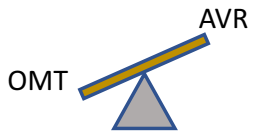

In the setting of LFLG AS, AVR has a not negligible perioperative mortality risk, significatively higher than in severe AS with preserved ejection fraction

OMT should be reserved to:

Complex patients at very high perioperative risk and low life expectancy

Patients with features suggesting low benefits from AVR (AVA proj $>1 \mathrm{~cm} 2$, $\mathrm{FLR}<200 \mathrm{ml}$ rather than the lack of FR at DSE)

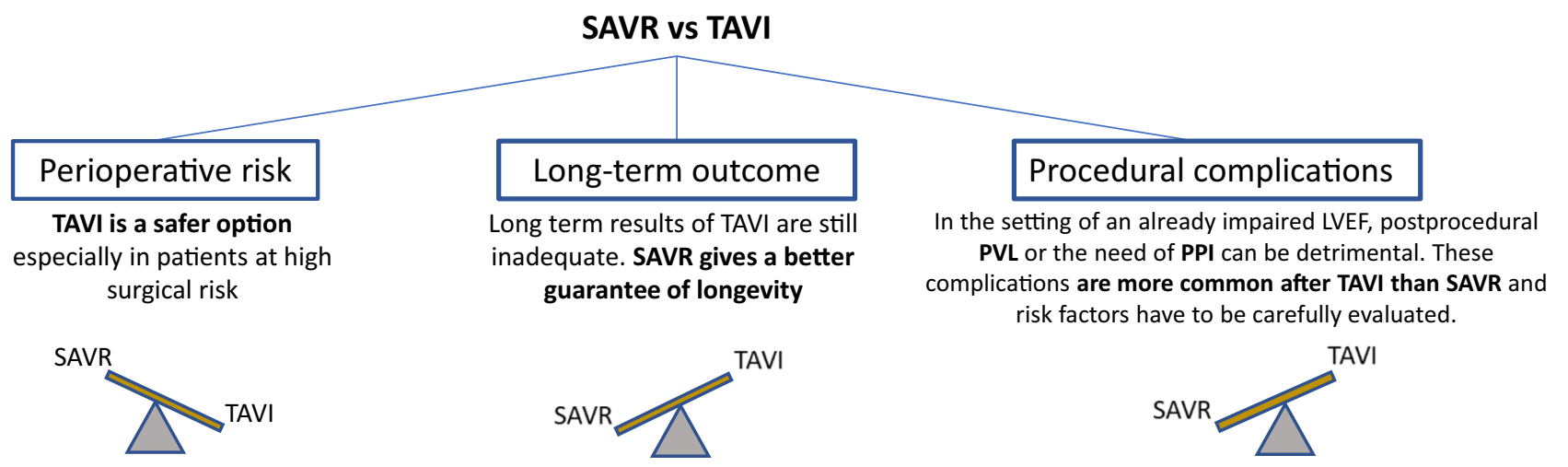

Fig. 2 Proposed algorithm for the management of severe lowflow low-gradient aortic stenosis. Abbreviations: AVR aortic valve replacement, AVAproj: projected aortic valve area; DSE: dobutamine stress echocardiography; FLR: transaortic flow rate at rest; FR: func- tional reserve; OMT: optimal medical therapy; PPI: permanent pacemaker implantation; PVL: paravalvular leak; SAVR: surgical aortic valve repair; TAVI: transcatheter aortic valve repair 
Table 3 TAVI vs SAVR overall mortality rate according to the majors TAVI RCTs

\begin{tabular}{|c|c|c|c|c|c|c|c|}
\hline & & \multicolumn{2}{|c|}{30 days } & \multicolumn{2}{|c|}{1 years } & \multicolumn{2}{|c|}{5 years } \\
\hline & & TAVI & SAVR & TAVI & SAVR & TAVI & SAVR \\
\hline \multirow{4}{*}{ High operative risk } & \multirow{2}{*}{$\begin{array}{c}\text { PARTNER } 1 \text { (29,37) } \\
\text { (Mean STS score } 11,8 \% \text { ) }\end{array}$} & $3,4 \%$ & $6,5 \%$ & $24,2 \%$ & $26,8 \%$ & $67,8 \%$ & $62,4 \%$ \\
\hline & & \multicolumn{2}{|c|}{ P 0,07 } & \multicolumn{2}{|c|}{ P 0,44 } & \multicolumn{2}{|c|}{ P 0,76 } \\
\hline & \multirow{2}{*}{$\begin{array}{c}\text { COREVALVE US } \\
\text { Pivotal High Risk Trial } \\
(30,38) \\
\text { (Mean STS score } 7,4 \% \text { ) }\end{array}$} & $3,3 \%$ & $4,5 \%$ & $14,2 \%$ & $19,1 \%$ & $55,3 \%$ & $55,4 \%$ \\
\hline & & \multicolumn{2}{|c|}{$P 0,43$} & \multicolumn{2}{|c|}{ P 0,04 } & \multicolumn{2}{|c|}{$P 0,5$} \\
\hline \multirow{5}{*}{$\begin{array}{c}\text { Intermediate-high } \\
\text { operative risk }\end{array}$} & \multirow{2}{*}{$\begin{array}{c}\text { PARTNER } 2 \text { (31,39) } \\
\text { (Mean STS score 5,8\%) }\end{array}$} & $3,4 \%$ & $4 \%$ & $11,8 \%$ & $13 \%$ & $46 \%$ & $42,1 \%$ \\
\hline & & \multicolumn{2}{|c|}{$P 0,48$} & \multicolumn{2}{|c|}{ P 0,44 } & \multicolumn{2}{|c|}{ HR 1,09 } \\
\hline & \multirow{3}{*}{$\begin{array}{c}\text { SURTAVI (32) } \\
\text { (Mean STS 4,5\%) }\end{array}$} & \multicolumn{6}{|c|}{ *Longest available follow-up at 2 years } \\
\hline & & $2,2 \%$ & $1,7 \%$ & $6,7 \%$ & $6,8 \%$ & $11,4 \%$ & $11,6 \%$ \\
\hline & & \multicolumn{2}{|c|}{$\begin{array}{l}\text { Difference + 0,5\% } \\
\text { Cl 95\%: - 0,9/1,8\% }\end{array}$} & \multicolumn{2}{|c|}{$\begin{array}{l}\text { Difference }-0,1 \% \\
\text { Cl 95\%:-2,7/2,4\% }\end{array}$} & \multicolumn{2}{|c|}{$\begin{array}{l}\text { Difference }-0,2 \% \\
\text { Cl 95\%: }-3,8 / 3,3 \%\end{array}$} \\
\hline \multirow{6}{*}{ Low operative risk } & \multirow[t]{2}{*}{$\begin{array}{c}\text { PARTNER } 3 \text { (33) } \\
\text { (Mean STS score 1,9\%) }\end{array}$} & $0,4 \%$ & $1,1 \%$ & $1 \%$ & $2,5 \%$ & \multirow{2}{*}{\multicolumn{2}{|c|}{ Still not available }} \\
\hline & & \multicolumn{2}{|c|}{$\begin{array}{c}\text { Treatment effect } \\
0,37[0.07-1,88] \\
\mathrm{Cl} 95 \%\end{array}$} & \multicolumn{2}{|c|}{$\begin{array}{c}\text { Treatment effect } \\
0,41[0,14-1,17] \\
\text { Cl } 95 \%\end{array}$} & & \\
\hline & \multirow{2}{*}{$\begin{array}{c}\text { EVOLUT LOW RISK } \\
\text { TRIAL (34) } \\
\text { (Mean STS score 1,9\%) }\end{array}$} & $0,5 \%$ & $0,8 \%$ & $2,4 \%$ & $2,9 \%$ & \multirow{2}{*}{\multicolumn{2}{|c|}{ Still not available }} \\
\hline & & \multicolumn{2}{|c|}{$\begin{array}{l}\text { Difference }-0,3 \% \\
\text { CI 95\%: }-1,2 / 0,6\end{array}$} & \multicolumn{2}{|c|}{$\begin{array}{l}\text { Difference }-0,5 \% \\
\mathrm{Cl} 95 \%:-2,4 / 1,3\end{array}$} & & \\
\hline & \multirow{2}{*}{$\begin{array}{c}\text { NOTION (35) } \\
\text { (Mean STS score 3\%) }\end{array}$} & $2,1 \%$ & $3,7 \%$ & $4,9 \%$ & $7,5 \%$ & $27,6 \%$ & $28,4 \%$ \\
\hline & & \multicolumn{2}{|c|}{$P 0,43$} & \multicolumn{2}{|c|}{$P 0,38$} & \multicolumn{2}{|c|}{ P 0,75 } \\
\hline
\end{tabular}

Medtronic CoreValve

Edwards Sapien 
To date, TAVI in TAVI procedures are anecdotical, but the extension of the indication to intermediate- and low-risk patients will probably increase the experience in the near future. Nevertheless, we can learn from the percutaneous treatment of degenerated surgically implanted bioprostheses (TAVI valve-in-valve procedure), already extensively described. The pivotal limiting factor for a second TAVI is the risk of coronary obstruction due to the displacement of the leaflets of the first bioprosthesis: a short and narrow aortic root represents an important risk factor [41]. Interestingly, different device combination could play a role in the success of TAVI in TAVI procedure and, in the future, might influence the choice of the first device to implant [42].

Even if TAVI is now an available option regardless of the surgical risk score, its use has to be cautious, especially in young and low-risk patients.

\section{Paravalvular leak}

PVL after TAVI is a common procedure-related complication: the overall incidence ranges between 50 and $85 \%$, significantly higher than PVL after SAVR (attested between 1 and 47.6\%), even though the majority of TAVIrelated PVL is mild (7.8-40.8\%) [43]. More than mild PVL has been associated with increased mortality in the overall TAVI population and a residual transaortic regurgitation can be especially detrimental for LFLG AS with an already dysfunctional heart [44]. Therefore, we have to take into account specific anatomical factors related to PVL while deciding between TAVI or SAVR. Shape, diameter, and extensive valve calcification of the aortic annulus are recognized risk factors: transcatheter bioprostheses can adapt with difficulty their rounded shape and anchor to an oval and wide aortic annulus, especially in presence of a high burden of calcium [45]. Even the type of TAVI device can play a role: the CHOICE trial [46] compared second generation balloon expandable vs self-expandable prostheses (Edwards Sapien XT and Medtronic CoreValve) showing a higher incidence of 30-day PVL in the selfexpandable group (incidence of more-than-mild PVL at angiographic assessment $4.1 \%$ for Edwards vs $18.3 \%$ for Corevalve, $P<0.001)$. Notably, the $71 \%$ of morethan-mild Corevalve-related PVL downgraded to mild at 1 year: this data related with the post-deployment radial force that the self-expandable device exerts on the aortic annulus. Nevertheless, the CHOICE trial described a higher progression of mild PVL to more severe degrees in the Corevalve group, defining a higher overall risk of PVL with CoreValve than with Edwards bioprostheses (1.1\% vs. $12.1 \% ; P=0.005$ ) [47]. Third generation TAVI (Edwards S3 and CoreValve Evolut R/PRO) has been specifically designed to reduce the incidence of aortic regurgitation and a recent study [48] confirmed better outcomes with both bioprostheses. CoreValve showed again a higher incidence of regurgitation but without a significant difference with the Edwards prostheses (incidence of more-than-mild PVL was $8.2 \%$ in CoreValve group vs $4.1 \%$ in Medtronic group, $p<0.1$ ) [48].

Bicuspid aortic valve (BAV) shows all of the three mentioned risk factors for PVL (elliptical annulus shape, wide annulus, and massive and asymmetric calcifications) and is also associated to prosthesis under-expansion, correlated to the risk of an accelerated valve deterioration. Even if according to actual guidelines [1,2], SAVR is the treatment of choice for BAV, the experience with percutaneous treatment is increasing, mostly consequently to several recent studies that failed to show significant outcome differences in respect to the replacement of tricuspid aortic valve (TAV). The largest available study on 5412 patients [49] comparing TAVI in BAV vs TAV showed a slightly higher incidence of residual moderate or severe PVL in BAV $(2.7 \%$ vs $2.1 \% ; P<0.001)$ but with a significant incidence reduction with new generation devices (Sapien 3 and Evolut R, 2.7\% vs $14 \% ; P<0.001)$. Another smaller (but with a propensity score-matched cohort analysis) observational study [50] showed similar results: an overall more frequent adverse procedural events in BAV group, without significant differences between BAV and TAV when new devices were used, irrespectively of the type of implanted prosthesis (Edwards Sapien 3, CoreValve Evolut $\mathrm{R}$ or Boston Scientific Lotus). Today, TAVI in BAV is a valuable option, especially when recurring to new generation prostheses. Nevertheless, the procedure deserves a carefully preoperative evaluation. In particular, the assessment of prosthesis size can be challenging even with preoperative CCT because of the distortion of BAV annulus; in this case, an intraoperative balloon sizing can avoid an oversized prosthesis. There are still doubts about the impact of BAV morphology on the procedural success: the presence of a calcified raphe has been linked to a higher incidence of PVL and permanent pacemaker implantation (PPI) [51]. Finally, it should be noticed that the patients with BAV who require AVR are medially younger than TAV patients; therefore, the considerations about life expectancy and prosthesis longevity have to be selectively made.

\section{Conduction disturbances}

PPI after AVR has been recently linked to a reduced longterm survival $[52,53]$. The risk of post-procedural need for PPI acquires a particular role during the preprocedural evaluation of LFLG AS. In fact, on the basis of the BLOCK-HF RCT results, latest pacing guidelines [54] suggest to prefer cardiac resynchronization therapy 
(CRT) to right ventricle pacing alone in patients with an impaired LVEF (EF $<50 \%)$. PPI need is relatively uncommon after SAVR (2-5\%); on the contrary, highdegree atrioventricular conduction disturbances are habitual complications after TAVI. According to the largest available meta-analyses [55, 56], the estimation of the real incidence of post-TAVI PPI is difficult because of the large inhomogeneity of the results of the studies and the evolution of the devices. The major risk factors are: pre-existing conduction disturbances (especially firstdegree atrio-ventricular block, left anterior fascicular block, and right bundle branch block), extensive aortic annulus calcifications (especially at the non-coronary cusp landing zone), pre-deployment valvuloplasty, deep device implantation, short length of membranous septum, and implantation of self-expandable devices [54, 55, 57]. Traditionally, balloon expandable prostheses have been associated with a lower rate of conduction disorders than the self-expandable ones but this gap is reducing with the new generation devices [54]. Despite PPI is not a negligible risk when TAVI is performed, the real need of long-term pacing has been recently questioned [58]: patients who receive pacemakers for intermittent conduction disturbances are most of the time no-pacing dependent at the following controls, suggesting the possible prolongation of the observational period before definitive electrical therapy.

New onset bundle branch blocks (especially left bundle branch block, LBBB) can be particularly detrimental in LFLG AS too; in fact, LBBB-related electrical and mechanical dyssynchrony can severely reduce the benefit of the afterload reduction obtained with AVR. New onset of LBBB after SAVR ranges between 4.4 and $4.6 \%[59,60]$. Nevertheless, new sutureless and rapid deployment surgical bioprostheses can markedly increase conduction disturbances, reaching an incidence of $16 \%$ [60]. Incidence of post-TAVI LBBB onset varies among papers, ranging from 15 to $20 \%$ [61, 62] with the same risk factors as PPI. There is still not consensus about the impact of TAVI-related branch blocks on patient prognosis. A large observational study which followed up 1020 patients treated with TAVI for a median time of 3 years failed to demonstrate a significant difference in terms of cardiovascular mortality or HF rehospitalization between patients with and without post-procedural LBBB [61], even if the LBBB group showed lower LVEF recovery. On the other hand, a sub-analysis from PARTNER II trial [62] followed up 1179 intermediate surgical risk patients treated with TAVI for 2 years showing significantly higher cardiovascular mortality and HF rehospitalization in new onset LBBB group. Although the baseline characteristics of the two study populations were similar, the overall mortality was particularly higher in the first study (43\% vs $11.7 \%$ ) and this could have influenced the prognostic impact of procedure-related LBBB. To date, there are few only anecdotical reports available about CRT after TAVIrelated $\mathrm{LBBB}$ with doubts related to the right timing and the real utility of CRT in this specific population. Usually, the recovery of LVEF occurs in the very first days after the procedure and the long-term follow-up does not show significant changes [18,63]. Therefore, early CRT implantation seems a reasonable option when early post-procedural echocardiography does not demonstrate a satisfactory LV function recovery. However, a recent study [64] questioned the usefulness of electrical resynchronization of AVR-related conduction disturbances: 140 patients were followed up for $19 \pm 9$ months after TAVI, among which the 20\% developed LBBB; 26 (98\%) did not meet echocardiographic criteria to define a dyssynchronous LBBB contraction pattern and there was no significant overall mortality difference between the two groups.

\section{Conclusion}

The management of LFLG AS with impaired LVEF is still challenging. Cardiologists have several tools to quantify the contribution of AV disease to the LV dysfunction and the lack of contractility reserve per se should not discourage further investigations to evaluate the possible benefit of the valve replacement. True severe LFLG AS has very poor prognosis on OMT alone and abstention from intervention should be reserved only to extremely critical patients. The coexistence of severe AS and impaired LVEF always concerns the Heart Team specialists and pushes towards a transcatheter approach that currently seems to guarantee a lower perioperative risk than the surgical treatment. To date, there are not enough data available about long-term outcome of TAVI. Therefore, especially in young subjects who are expected to gain a significant benefit from AVR and with a good life expectancy, the choice of the best treatment has to be carefully evaluated, even discussing with the patient itself about pros and cons of both solutions. Finally, the decision between TAVI and SAVR imposes a comprehensive short-term and long-term risk evaluation, especially when pre-existent factors can predispose to a suboptimal transcatheter treatment. Further studies and sub-analysis of the large available RCTs are needed to help clinicians in the management of this LFLG AS with reduced LVEF.

Funding Open access funding provided by Università degli Studi di Siena within the CRUI-CARE Agreement. 


\section{Declarations}

Conflict of interest The authors declare that they have no conflict of interest.

Open Access This article is licensed under a Creative Commons Attribution 4.0 International License, which permits use, sharing, adaptation, distribution and reproduction in any medium or format, as long as you give appropriate credit to the original author(s) and the source, provide a link to the Creative Commons licence, and indicate if changes were made. The images or other third party material in this article are included in the article's Creative Commons licence, unless indicated otherwise in a credit line to the material. If material is not included in the article's Creative Commons licence and your intended use is not permitted by statutory regulation or exceeds the permitted use, you will need to obtain permission directly from the copyright holder. To view a copy of this licence, visit http://creativecommons.org/licenses/by/4.0/.

\section{References}

1. Baumgartner H, Falk V, Bax JJ, De Bonis M, Hamm C, Holm PJ, Iung B, Lancellotti P, Lansac E, Rodriguez Muñoz D, Rosenhek R, Sjögren J, Tornos Mas P, Vahanian A, Walther T, Wendler O, Windecker S, Zamorano JL (2017) ESC Scientific Document Group. 2017 ESC/EACTS Guidelines for the management of valvular heart disease. Eur Heart J. 21;38(36):2739-91. https://doi.org/10.1093/ eurheartj/ehx391. PMID: 28886619.

2. Otto CM, Nishimura RA, Bonow RO, Carabello BA, Erwin JP 3rd, Gentile F, Jneid H, Krieger EV, Mack M, McLeod C, O'Gara PT, Rigolin VH, Sundt TM 3rd, Thompson A, Toly C (2020) ACC/ AHA Guideline for the Management of Patients With Valvular Heart Disease: Executive Summary: A Report of the American College of Cardiology/American Heart Association Joint Committee on Clinical Practice Guidelines. Circulation. 2020 Dec 17:CIR0000000000000932. https://doi.org/10.1161/CIR.00000 00000000932. Epub ahead of print. PMID: 33332149.Samad Z et al. Aortic valve surgery and survival in patients with moderate or severe aortic stenosis and left ventricular dysfunction. Eur Heart J. $2016 \mathrm{Jul}$ 21;37(28):2276-86. https://doi.org/10.1093/eurheartj/ehv701.

3. Blais C, Burwash IG, Mundigler G, Dumesnil JG, Loho N, Rader F, Baumgartner H, Beanlands RS, Chayer B, Kadem L, Garcia D, Durand LG, Pibarot P (2006) Projected valve area at normal flow rate improves the assessment of stenosis severity in patients with low-flow, low-gradient aortic stenosis: the multicenter TOPAS (Truly or PseudoSevere Aortic Stenosis) study. Circulation 113(5):711-721. https://doi. org/10.1161/CIRCULATIONAHA.105.557678 (PMID: 16461844)

4. Clavel MA, Burwash IG, Mundigler G, Dumesnil JG, Baumgartner H, Bergler-Klein J, Sénéchal M, Mathieu P, Couture C, Beanlands R, Pibarot P (2010) Validation of conventional and simplified methods to calculate projected valve area at normal flow rate in patients with low flow, low gradient aortic stenosis: the multicenter TOPAS (True or Pseudo Severe Aortic Stenosis) study J Am Soc Echocardiogr 234380 386https://doi.org/10.1016/j. echo.2010.02.0022010 PMID:20362927 Lennartvan Gils et al. Prognostic Implications of Moderate Aortic Stenosisin Patients With Left Ventricular Systolic Dysfunction J Am Coll Cardiol 2017 https://doi. org/10.1016/j.jacc.2017.03.0232017

5. Annabi MS, Touboul E, Dahou A, Burwash IG, Bergler-Klein J, Enriquez-Sarano M, Orwat S, Baumgartner H, Mascherbauer J, Mundigler G, Cavalcante JL, Larose É, Pibarot P, Clavel MA (2018) Dobutamine stress echocardiography for management of low-flow, lowgradient aortic stenosis. J Am Coll Cardiol 71(5):475-485. https:// doi.org/10.1016/j.jacc.2017.11.0522017.11.0522017.11.0522017. 11.052(PMID: 29406851)

6. Chahal NS, Drakopoulou M, Gonzalez-Gonzalez AM, Manivarmane R, Khattar R, Senior R (2015) Resting aortic valve area at normal transaortic flow rate reflects true valve area in suspected low-gradient severe aortic stenosis. JACC Cardiovasc Imaging 8(10):1133-1139. https://doi.org/10.1016/j.jcmg.2015.04.0212015.04.0212015. 04.0212015.04.021Epub 2015 Sep 9 PMID: 26363832)

7. Koos R, Mahnken AH, Sinha AM, Wildberger JE, Hoffmann R, Kühl HP (2004) Aortic valve calcification as a marker for aortic stenosis severity: assessment on 16-MDCT. AJR Am J Roentgenol 183(6):1813-1818. https://doi.org/10.2214/ajr.183.6.01831813 (PMID: 15547235)

8. Pawade T, Clavel MA, Tribouilloy C, Dreyfus J, Mathieu T, Tastet L, Renard C, Gun M, Jenkins WSA, Macron L, Sechrist JW, Lacomis JM, Nguyen V, Galian Gay L, Cuéllar Calabria H, Ntalas I, Cartlidge TRG, Prendergast B, Rajani R, Evangelista A, Cavalcante JL, Newby DE, Pibarot P, Messika Zeitoun D, Dweck MR (2018) Computed tomography aortic valve calcium scoring in patients with aortic stenosis. Circ Cardiovasc Imaging 11(3):e007146. https://doi. org/10.1161/CIRCIMAGING.117.007146 (PMID: 29555836)

9. Messika-Zeitoun D, Aubry MC, Detaint D, Bielak LF, Peyser PA, Sheedy PF, Turner ST, Breen JF, Scott C, Tajik AJ, EnriquezSarano M (2004) Evaluation and clinical implications of aortic valve calcification measured by electron-beam computed tomography. Circulation 110(3):356-362. https://doi.org/10.1161/01.CIR. 0000135469.82545.D0 (Epub 2004 Jul 12 PMID: 15249504)

10. Clavel MA, Messika-Zeitoun D, Pibarot P, Aggarwal SR, Malouf J, Araoz PA, Michelena HI, Cueff C, Larose E, Capoulade R, Vahanian A, Enriquez-Sarano M (2013) The complex nature of discordant severe calcified aortic valve disease grading: new insights from combined Doppler echocardiographic and computed tomographic study. J Am Coll Cardiol 62(24):2329-2338. https:// doi.org/10.1016/j.jacc.2013.08.16212013.08.16212013.08. 16212013.08.1621(Epub 2013 Sep 24 PMID: 24076528)

11. Clavel MA, Pibarot P, Messika-Zeitoun D, Capoulade R, Malouf J, Aggarval S, Araoz PA, Michelena HI, Cueff C, Larose E, Miller JD, Vahanian A, Enriquez-Sarano M (2014) Impact of aortic valve calcification, as measured by MDCT, on survival in patients with aortic stenosis: results of an international registry study. $\mathrm{J}$ Am Coll Cardiol 64(12):1202-1213. https://doi.org/10.1016/j. jacc.2014.05.066.PMID:25236511;PMCID:PMC4391203

12. Pinto Teixeira P, Ramos R, Rio P, Moura Branco L, Portugal G, Abreu A, Galrinho A, Marques H, Figueiredo L, Cruz FR (2017) Modified continuity equation using left ventricular outflow tract three-dimensional imaging for aortic valve area estimation. Echocardiography 34(7):978-985. https://doi.org/10.1111/ echo.13589 (Epub 2017 Jun 7 PMID: 28589708)

13. Bohbot Y, Renard C, Manrique A, Levy F, Maréchaux S, Gerber BL, Tribouilloy C. Usefulness of Cardiac Magnetic Resonance Imaging in Aortic Stenosis. Circ Cardiovasc Imaging. 2020 May;13(5):e010356. doi: https://doi.org/10.1161/CIRCIMAGING.119.010356. Epub 2020 May 6. PMID: 32370617.

14. Samad Z, Vora AN, Dunning A, Schulte PJ, Shaw LK, Al-Enezi F, Ersboll M, McGarrah RW 3rd, Vavalle JP, Shah SH, Kisslo J, Glower D, Harrison JK, Velazquez EJ. Aortic valve surgery and survival in patients with moderate or severe aortic stenosis and left ventricular dysfunction. Eur Heart J. 2016 Jul 21;37(28):2276-86. doi: https:// doi.org/10.1093/eurheartj/ehv701. Epub 2016 Jan 18. PMID: 26787441; PMCID: PMC5841220.

15. Van Gils L, Clavel MA, Vollema EM, Hahn RT, Spitzer E, Delgado V, Nazif T, De Jaegere PP, Geleijnse ML, Ben-Yehuda O, Bax JJ, Leon MB, Pibarot P, Van Mieghem NM (2017) Prognostic implications of moderate aortic stenosis in patients with left ventricular systolic dysfunction. J Am Coll Cardiol 69(19):2383-2392. 
https://doi.org/10.1016/j.jacc.2017.03.0232017.03.0232017. 03.0232017.03.023(PMID: 28494976)

16. Spitzer E, Van Mieghem NM, Pibarot P, Hahn RT, Kodali S, Maurer MS, Nazif TM, Rodés-Cabau J, Paradis JM, Kappetein AP, BenYehuda O, van Es GA, Kallel F, Anderson WN, Tijssen J, Leon MB (2016) Rationale and design of the Transcatheter Aortic Valve Replacement to UNload the Left ventricle in patients with ADvanced heart failure (TAVR UNLOAD) trial. Am Heart J 182:80-88. https:// doi.org/10.1016/j.ahj.2016.08.0092016.08.0092016.08.0092016. 08.009(Epub 2016 Aug 26 PMID: 27914503)

17. Sato K, Sankaramangalam K, Kandregula K, Bullen JA, Kapadia SR, Krishnaswamy A, Mick S, Rodriguez LL, Grimm RA, Menon V, Desai MY, Svensson LG, Griffin BP, Popović ZB (2019) Contemporary outcomes in low-gradient aortic stenosis patients who underwent dobutamine stress echocardiography. J Am Heart Assoc 8(6):e011168. https://doi.org/10.1161/JAHA.118.011168 .PMID:30 879370;PMCID:PMC6475055

18. Tribouilloy C, Lévy F, Rusinaru D, Guéret P, Petit-Eisenmann H, Baleynaud S, Jobic Y, Adams C, Lelong B, Pasquet A, Chauvel C, Metz D, Quéré JP, Monin JL (2009) Outcome after aortic valve replacement for low-flow/low-gradient aortic stenosis without contractile reserve on dobutamine stress echocardiography. J Am Coll Cardiol 53(20):1865-1873. https://doi.org/10.1016/j. jacc.2009.02.0262009.02.026(PMID: 19442886)

19. Monin JL, Quéré JP, Monchi M, Petit H, Baleynaud S, Chauvel C, Pop C, Ohlmann P, Lelguen C, Dehant P, Tribouilloy C, Guéret P (2003) Low-gradient aortic stenosis: operative risk stratification and predictors for long-term outcome: a multicenter study using dobutamine stress hemodynamics. Circulation 108(3):319-324. https://doi.org/10.1161/01.CIR.0000079171.43055.46 (Epub 2003 Jun 30 PMID: 12835219)

20. Herrmann HC, Pibarot P, Hueter I, Gertz ZM, Stewart WJ, Kapadia S, Tuzcu EM, Babaliaros V, Thourani V, Szeto WY, Bavaria JE, Kodali S, Hahn RT, Williams M, Miller DC, Douglas PS, Leon MB (2013) Predictors of mortality and outcomes of therapy in low-flow severe aortic stenosis: a Placement of Aortic Transcatheter Valves (PARTNER) trial analysis. Circulation 127(23):2316-2326. https:// doi.org/10.1161/CIRCULATIONAHA.112.001290 (Epub 2013 May 9 PMID: 23661722)

21. Clavel MA, Fuchs C, Burwash IG, Mundigler G, Dumesnil JG, Baumgartner H, Bergler-Klein J, Beanlands RS, Mathieu P, Magne J, Pibarot P (2008) Predictors of outcomes in low-flow, lowgradient aortic stenosis: results of the multicenter TOPAS Study. Circulation 118(14 Suppl):S234-S242. https://doi.org/10.1161/ CIRCULATIONAHA.107.757427 (PMID: 18824760)

22. Ribeiro HB, Lerakis S, Gilard M, Cavalcante JL, Makkar R, Herrmann HC, Windecker S, Enriquez-Sarano M, Cheema AN, Nombela-Franco L, Amat-Santos I, Muñoz-García AJ, Garcia Del Blanco B, Zajarias A, Lisko JC, Hayek S, Babaliaros V, Le Ven F, Gleason TG, Chakravarty T, Szeto WY, Clavel MA, de Agustin A, Serra V, Schindler JT, Dahou A, Puri R, Pelletier-Beaumont E, Côté M, Pibarot P, Rodés-Cabau J (2018) Transcatheter aortic valve replacement in patients with low-flow, low-gradient aortic stenosis: The TOPAS-TAVI Registry. J Am Coll Cardiol 71(12):1297-1308. https://doi.org/10.1016/j.jacc.2018.01.0542018.01.054(PMID: 29566812)

23. Levy F, Laurent M, Monin JL, Maillet JM, Pasquet A, Le Tourneau T, Petit-Eisenmann H, Gori M, Jobic Y, Bauer F, Chauvel C, Leguerrier A, Tribouilloy C (2008) Aortic valve replacement for low-flow/low-gradient aortic stenosis operative risk stratification and long-term outcome: a European multicenter study. J Am Coll Cardiol 51(15):1466-1472. https://doi.org/10.1016/j. jacc.2007.10.067(PMID: 18402902)

24. Mangner N, Stachel G, Woitek F, Haussig S, Schlotter F, Höllriegel R, Adam J, Lindner A, Mohr FW, Schuler G, Kiefer P, Leontyev S, Borger MA, Thiele H, Holzhey D, Linke A (2018) Predictors of mortality and symptomatic outcome of patients with low-flow severe aortic stenosis undergoing transcatheter aortic valve replacement. J Am Heart Assoc 7(8):e007977.https://doi.org/10.1161/ JAHA.117.007977 .PMID:29654191;PMCID:PMC6015421

25. Fischer-Rasokat U, Renker M, Liebetrau C, van Linden A, Arsalan M, Weferling M, Rolf A, Doss M, Möllmann H, Walther T, Hamm CW, Kim WK (2019) 1-Year survival after TAVR of patients with low-flow, low-gradient and high-gradient aortic valve stenosis in matched study populations. JACC Cardiovasc Interv 12(8):752-763. https://doi.org/10.1016/j.jcin.2019.01.233(PMID: 31000012)

26. Buchanan KD, Rogers T, Steinvil A, Koifman E, Xu L, Torguson R, Okubagzi PG, Shults C, Pichard AD, Ben-Dor I, Satler LF, Waksman R, Asch FM (2019) Role of contractile reserve as a predictor of mortality in low-flow, low-gradient severe aortic stenosis following transcatheter aortic valve replacement. Catheter Cardiovasc Interv 93(4):707-712. https://doi.org/10.1002/ccd.27914 (Epub 2018 Oct 2 PMID: 30280469)

27. Vamvakidou A, Jin W, Danylenko O, Chahal N, Khattar R, Senior R (2019) Low transvalvular flow rate predicts mortality in patients with low-gradient aortic stenosis following aortic valve intervention. JACC Cardiovasc Imaging 12(9):1715-1724. https://doi.org/10.1016/j. jcmg.2018.01.011(Epub 2018 Mar 14 PMID: 29550315)

28. Rosa VEE, Ribeiro HB, Sampaio RO, Morais TC, Rosa MEE, Pires LJT, Vieira MLC, Mathias W Jr, Rochitte CE, de Santis ASAL, Fernandes JRC, Accorsi TAD, Pomerantzeff PMA, Rodés-Cabau J, Pibarot P, Tarasoutchi F (2019) Myocardial fibrosis in classical low-flow, low-gradient aortic stenosis. Circ Cardiovasc Imaging 12(5):e008353. https://doi.org/10.1161/CIRCIMAGING.118.008353 (PMID: 31088148)

29. Smith CR, Leon MB, Mack MJ, Miller DC, Moses JW, Svensson LG, Tuzcu EM, Webb JG, Fontana GP, Makkar RR, Williams M, Dewey T, Kapadia S, Babaliaros V, Thourani VH, Corso P, Pichard AD, Bavaria JE, Herrmann HC, Akin JJ, Anderson WN, Wang D, Pocock SJ; PARTNER Trial Investigators. Transcatheter versus surgical aortic-valve replacement in high-risk patients. N Engl J Med. 2011 Jun 9;364(23):2187-98. https://doi.org/10.1056/NEJMoa1103510. Epub 2011 Jun 5. PMID: 21639811.

30. Adams DH, Popma JJ, Reardon MJ, Yakubov SJ, Coselli JS, Deeb GM, Gleason TG, Buchbinder M, Hermiller J Jr, Kleiman NS, Chetcuti S, Heiser J, Merhi W, Zorn G, Tadros P, Robinson N, Petrossian G, Hughes GC, Harrison JK, Conte J, Maini B, Mumtaz M, Chenoweth S, Oh JK; U.S. CoreValve Clinical Investigators. Transcatheter aortic-valve replacement with a self-expanding prosthesis. N Engl J Med. 2014 May 8;370(19):1790-8. https:// doi.org/10.1056/NEJMoa1400590. Epub 2014 Mar 29. PMID: 24678937.

31. Leon MB, Smith CR, Mack MJ, Makkar RR, Svensson LG, Kodali SK, Thourani VH, Tuzcu EM, Miller DC, Herrmann HC, Doshi D, Cohen DJ, Pichard AD, Kapadia S, Dewey T, Babaliaros V, Szeto WY, Williams MR, Kereiakes D, Zajarias A, Greason KL, Whisenant BK, Hodson RW, Moses JW, Trento A, Brown DL, Fearon WF, Pibarot P, Hahn RT, Jaber WA, Anderson WN, Alu MC, Webb JG; PARTNER 2 Investigators. Transcatheter or Surgical Aortic-Valve Replacement in Intermediate-Risk Patients. N Engl J Med. 2016 Apr 28;374(17):1609-20. https://doi.org/10.1056/NEJMoa1514616. Epub 2016 Apr 2. PMID: 27040324.

32. Reardon MJ, Van Mieghem NM, Popma JJ, Kleiman NS, Søndergaard L, Mumtaz M, Adams DH, Deeb GM, Maini B, Gada H, Chetcuti S, Gleason T, Heiser J, Lange R, Merhi W, Oh JK, Olsen PS, Piazza N, Williams M, Windecker S, Yakubov SJ, Grube E, Makkar R, Lee JS, Conte J, Vang E, Nguyen H, Chang Y, Mugglin AS, Serruys PW, Kappetein AP; SURTAVI Investigators. Surgical or Transcatheter Aortic-Valve Replacement in Intermediate-Risk Patients. N Engl J Med. 2017 Apr 6;376(14):1321-1331. https:// doi.org/10.1056/NEJMoa1700456. Epub 2017 Mar 17. PMID: 28304219 . 
33. Mack MJ, Leon MB, Thourani VH, Makkar R, Kodali SK, Russo M, Kapadia SR, Malaisrie SC, Cohen DJ, Pibarot P, Leipsic J, Hahn RT, Blanke P, Williams MR, McCabe JM, Brown DL, Babaliaros V, Goldman S, Szeto WY, Genereux P, Pershad A, Pocock SJ, Alu MC, Webb JG, Smith CR; PARTNER 3 Investigators. Transcatheter Aortic-Valve Replacement with a Balloon-Expandable Valve in LowRisk Patients. N Engl J Med. 2019 May 2;380(18):1695-1705. https:// doi.org/10.1056/NEJMoa1814052. Epub 2019 Mar 16. PMID: 30883058.

34. Popma JJ, Deeb GM, Yakubov SJ, Mumtaz M, Gada H, O'Hair D, Bajwa T, Heiser JC, Merhi W, Kleiman NS, Askew J, Sorajja P, Rovin J, Chetcuti SJ, Adams DH, Teirstein PS, Zorn GL 3rd, Forrest JK, Tchétché D, Resar J, Walton A, Piazza N, Ramlawi B, Robinson N, Petrossian G, Gleason TG, Oh JK, Boulware MJ, Qiao H, Mugglin AS, Reardon MJ; Evolut Low Risk Trial Investigators. Transcatheter Aortic-Valve Replacement with a Self-Expanding Valve in Low-Risk Patients. N Engl J Med. 2019 May 2;380(18):1706-1715. https:// doi.org/10.1056/NEJMoa1816885. Epub 2019 Mar 16. PMID: 30883053.

35. Thyregod HG, Steinbrüchel DA, Ihlemann N, Nissen H, Kjeldsen BJ, Petursson P, Chang Y, Franzen OW, Engstrøm T, Clemmensen P, Hansen PB, Andersen LW, Olsen PS, Søndergaard L (2015) Transcatheter versus surgical aortic valve replacement in patients with severe aortic valve stenosis: 1-year results from the allComers NOTION Randomized Clinical Trial. J Am Coll Cardiol 65(20):2184-2194. https://doi.org/10.1016/j.jacc.2015.03.0142015 (Epub 2015 Mar 15 PMID: 25787196)

36. Siontis GC, Praz F, Pilgrim T, Mavridis D, Verma S, Salanti G, Søndergaard L, Jüni P, Windecker S. Transcatheter aortic valve implantation vs. surgical aortic valve replacement for treatment of severe aortic stenosis: a meta-analysis of randomized trials. Eur Heart J. 2016 Dec 14;37(47):3503-3512. https://doi.org/10.1093/eurheartj/ ehw225. Epub 2016 Jul 7. PMID: 27389906.

37. Kapadia SR, Leon MB, Makkar RR, Tuzcu EM, Svensson LG, Kodali S, Webb JG, Mack MJ, Douglas PS, Thourani VH, Babaliaros VC, Herrmann HC, Szeto WY, Pichard AD, Williams MR, Fontana GP, Miller DC, Anderson WN, Akin JJ, Davidson MJ, Smith CR; PARTNER trial investigators. 5-year outcomes of transcatheter aortic valve replacement compared with standard treatment for patients with inoperable aortic stenosis (PARTNER 1): a randomised controlled trial. Lancet. 2015 Jun 20;385(9986):2485-91. https://doi. org/10.1016/S0140-6736(15)60290-2. Epub 2015 Mar 15. PMID: 25788231.

38. Gleason TG, Reardon MJ, Popma JJ, Deeb GM, Yakubov SJ, Lee JS, Kleiman NS, Chetcuti S, Hermiller JB Jr, Heiser J, Merhi W, Zorn GL 3rd, Tadros P, Robinson N, Petrossian G, Hughes GC, Harrison JK, Conte JV, Mumtaz M, Oh JK, Huang J, Adams DH; CoreValve U.S. Pivotal High Risk Trial Clinical Investigators. 5-Year Outcomes of Self-Expanding Transcatheter Versus Surgical Aortic Valve Replacement in High-Risk Patients. J Am Coll Cardiol. 2018 Dec 4;72(22):2687-2696. https://doi.org/10.1016/j.jacc.2018.08.2146. Epub 2018 Sep 21. PMID: 30249462.

39. Makkar RR, Thourani VH, Mack MJ, Kodali SK, Kapadia S, Webb JG, Yoon SH, Trento A, Svensson LG, Herrmann HC, Szeto WY, Miller DC, Satler L, Cohen DJ, Dewey TM, Babaliaros V, Williams MR, Kereiakes DJ, Zajarias A, Greason KL, Whisenant BK, Hodson RW, Brown DL, Fearon WF, Russo MJ, Pibarot P, Hahn RT, Jaber WA, Rogers E, Xu K, Wheeler J, Alu MC, Smith CR, Leon MB; PARTNER 2 Investigators. Five-Year Outcomes of Transcatheter or Surgical Aortic-Valve Replacement. N Engl J Med. 2020 Jan 29;382(9):799-809. https://doi.org/10.1056/NEJMoa1910555. PMID: 31995682.

40. Blackman DJ, Saraf S, MacCarthy PA, Myat A, Anderson SG, Malkin CJ, Cunnington MS, Somers K, Brennan P, Manoharan G, Parker J, Aldalati O, Brecker SJ, Dowling C, Hoole SP, Dorman S, Mullen M, Kennon S, Jerrum M, Chandrala P, Roberts DH, Tay J,
Doshi SN, Ludman PF, Fairbairn TA, Crowe J, Levy RD, Banning AP, Ruparelia N, Spence MS, Hildick-Smith D (2019) Long-term durability of transcatheter aortic valve prostheses. J Am Coll Cardiol 73(5):537-545. https://doi.org/10.1016/j.jacc.2018.10.0782018 (PMID: 30732706)

41. Edelman JJ, Khan JM, Rogers T, Shults C, Satler LF, Ben-Dor II, Waksman R, Thourani VH (2019) Valve-in-valve TAVR: stateof-the-art review. Innovations (Phila) 14(4):299-310. https:// doi.org/10.1177/1556984519858020 (Epub 2019 Jul 22 PMID: 31328655)

42. Hatoum H, Yousefi A, Lilly S, Maureira P, Crestanello J, Dasi LP. An in vitro evaluation of turbulence after transcatheter aortic valve implantation. J Thorac Cardiovasc Surg. 2018 Nov;156(5):18371848. https://doi.org/10.1016/j.jtcvs.2018.05.0422018. Epub 2018 Jun 2. PMID: 29961588; PMCID: PMC6196367.

43. Lerakis S, Hayek SS, Douglas PS (2013) Paravalvular aortic leak after transcatheter aortic valve replacement: current knowledge. Circulation 127(3):397-407. https://doi.org/10.1161/CIRCULATIONAHA. 112.142000 (PMID: 23339094)

44. Athappan G, Patvardhan E, Tuzcu EM, Svensson LG, Lemos PA, Fraccaro C, Tarantini G, Sinning JM, Nickenig G, Capodanno D, Tamburino C, Latib A, Colombo A, Kapadia SR (2013) Incidence, predictors, and outcomes of aortic regurgitation after transcatheter aortic valve replacement: meta-analysis and systematic review of literature. J Am Coll Cardiol 61(15):1585-1595. https://doi. org/10.1016/j.jacc.2013.01.0472013(PMID: 23500308)

45. Wilczek K, Bujak K, Reguła R, Chodór P, Osadnik T. Risk factors for paravalvular leak after transcatheter aortic valve implantation. Kardiochir Torakochirurgia Pol. 2015 Jun;12(2):89-94. https://doi. org/10.5114/kitp.2015.528482015.52848. Epub 2015 Jun 30. PMID: 26336489; PMCID: PMC4550021.

46. Abdel-Wahab M, Mehilli J, Frerker C, Neumann FJ, Kurz T, Tölg R, Zachow D, Guerra E, Massberg S, Schäfer U, El-Mawardy M, Richardt G; CHOICE investigators. Comparison of balloon-expandable vs self-expandable valves in patients undergoing transcatheter aortic valve replacement: the CHOICE randomized clinical trial. JAMA. 2014 Apr 16;311(15):1503-14. https://doi.org/10.1001/ jama.2014.33162014. PMID: 24682026.

47. Abdel-Wahab M, Neumann FJ, Mehilli J, Frerker C, Richardt D, Landt M, Jose J, Toelg R, Kuck KH, Massberg S, Robinson DR, El-Mawardy M, Richardt G; CHOICE Investigators. 1-Year Outcomes After Transcatheter Aortic Valve Replacement With BalloonExpandable Versus Self-Expandable Valves: Results From the CHOICE Randomized Clinical Trial. J Am Coll Cardiol. 2015 Aug 18;66(7):791-800. https://doi.org/10.1016/j.jacc.2015.06.0262015. PMID: 26271061.

48. Rogers T, Steinvil A, Buchanan K, Alraies MC, Koifman E, Gai J, Torguson R, Okubagzi P, Ben-Dor I, Pichard A, Satler L, Waksman $\mathrm{R}$ (2017) Contemporary transcatheter aortic valve replacement with third-generation balloon-expandable versus self-expanding devices. J Interv Cardiol 30(4):356-361. https://doi.org/10.1111/joic.12389 (Epub 2017 May 11 PMID: 28493389)

49. Halim SA, Edwards FH, Dai D, Li Z, Mack MJ, Holmes DR, Tuzcu EM, Thourani VH, Harrison JK, Brennan JM (2020) Outcomes of transcatheter aortic valve replacement in patients with bicuspid aortic valve disease: a report from the Society of Thoracic Surgeons/American College of Cardiology Transcatheter Valve Therapy Registry. Circulation 141(13):1071-1079. https://doi.org/10.1161/CIRCULATIONAHA. 119.040333 (Epub 2020 Feb 26 PMID: 32098500)

50. Yoon SH, Bleiziffer S, De Backer O, Delgado V, Arai T, Ziegelmueller J, Barbanti M, Sharma R, Perlman GY, Khalique OK, Holy EW, Saraf S, Deuschl F, Fujita B, Ruile P, Neumann FJ, Pache G, Takahashi M, Kaneko H, Schmidt T, Ohno Y, Schofer N, Kong WKF, Tay E, Sugiyama D, Kawamori H, Maeno Y, Abramowitz Y, Chakravarty T, Nakamura M, Kuwata S, Yong G, Kao HL, Lee M, Kim HS, Modine T, Wong SC, Bedgoni F, Testa L, Teiger E, 
Butter C, Ensminger SM, Schaefer U, Dvir D, Blanke P, Leipsic J, Nietlispach F, Abdel-Wahab M, Chevalier B, Tamburino C, HildickSmith D, Whisenant BK, Park SJ, Colombo A, Latib A, Kodali SK, Bax JJ, Søndergaard L, Webb JG, Lefèvre T, Leon MB, Makkar R (2017) Outcomes in transcatheter aortic valve replacement for bicuspid versus tricuspid aortic valve stenosis. J Am Coll Cardiol 69(21):2579-2589. https://doi.org/10.1016/j.jacc.2017.03.0172017 (Epub 2017 Mar 18 PMID: 28330793)

51. Mylotte D, Lefevre T, Søndergaard L, Watanabe Y, Modine T, Dvir D, Bosmans J, Tchetche D, Kornowski R, Sinning JM, ThériaultLauzier P, O'Sullivan CJ, Barbanti M, Debry N, Buithieu J, Codner P, Dorfmeister M, Martucci G, Nickenig G, Wenaweser P, Tamburino C, Grube E, Webb JG, Windecker S, Lange R, Piazza N (2014) Transcatheter aortic valve replacement in bicuspid aortic valve disease. J Am Coll Cardiol 64(22):2330-2339. https://doi.org/10.1016/j. jacc.2014.09.0392014(Epub 2014 Dec 1 PMID: 25465419)

52. Mehaffey JH, Haywood NS, Hawkins RB, Kern JA, Teman NR, Kron IL, Yarboro LT, Ailawadi G. Need for Permanent Pacemaker After Surgical Aortic Valve Replacement Reduces Long-Term Survival. Ann Thorac Surg. 2018 Aug;106(2):460-465. https:// doi.org/10.1016/j.athoracsur.2018.02.0412018. Epub 2018 Mar 22. PMID: 29577930; PMCID: PMC6057813.

53. Jørgensen TH, De Backer O, Gerds TA, Bieliauskas G, Svendsen JH, Søndergaard L (2019) Mortality and heart failure hospitalization in patients with conduction abnormalities after transcatheter aortic valve replacement. JACC Cardiovasc Interv 12(1):52-61. https://doi. org/10.1016/j.jcin.2018.10.0532018(PMID: 30621978)

54. Brignole M, Auricchio A, Baron-Esquivias G, Bordachar P, Boriani G, Breithardt OA, Cleland J, Deharo JC, Delgado V, Elliott PM, Gorenek B, Israel CW, Leclercq C, Linde C, Mont L, Padeletti L, Sutton R, Vardas PE; ESC Committee for Practice Guidelines (CPG), Zamorano JL, Achenbach S, Baumgartner H, Bax JJ, Bueno H, Dean V, Deaton C, Erol C, Fagard R, Ferrari R, Hasdai D, Hoes AW, Kirchhof P, Knuuti J, Kolh P, Lancellotti P, Linhart A, Nihoyannopoulos P, Piepoli MF, Ponikowski P, Sirnes PA, Tamargo JL, Tendera M, Torbicki A, Wijns W, Windecker S; Document Reviewers, Kirchhof P, Blomstrom-Lundqvist C, Badano LP, Aliyev F, Bänsch D, Baumgartner H, Bsata W, Buser P, Charron P, Daubert JC, Dobreanu D, Faerestrand S, Hasdai D, Hoes AW, Le Heuzey JY, Mavrakis H, McDonagh T, Merino JL, Nawar MM, Nielsen JC, Pieske B, Poposka L, Ruschitzka F, Tendera M, Van Gelder IC, Wilson CM (2013) ESC Guidelines on cardiac pacing and cardiac resynchronization therapy: the Task Force on cardiac pacing and resynchronization therapy of the European Society of Cardiology (ESC). Developed in collaboration with the European Heart Rhythm Association (EHRA). Eur Heart J. 2013 Aug;34(29):2281-329. https://doi.org/10.1093/eurheartj/eht150. Epub 2013 Jun 24. PMID: 23801822.

55. van Rosendael PJ, Delgado V, Bax JJ (2018) Pacemaker implantation rate after transcatheter aortic valve implantation with early and newgeneration devices: a systematic review. Eur Heart J 39(21):20032013. https://doi.org/10.1093/eurheartj/ehx785 (PMID: 29420704)

56. Siontis GC, Jüni P, Pilgrim T, Stortecky S, Büllesfeld L, Meier B, Wenaweser P, Windecker S (2014) Predictors of permanent pacemaker implantation in patients with severe aortic stenosis undergoing TAVR: a meta-analysis. J Am Coll Cardiol 64(2):129-140. https://doi. org/10.1016/j.jacc.2014.04.0332014(PMID: 25011716)
57. Kassier A, Schuitema J, Berner M, ManandharShrestha N, Jovinge S, Gauri A, Frost J, Merh W, and Chalfoun N Length of membranous septum post implant predicts risk for permanent pacemaker placement and pacing requirements after trans-catheter aortic valve replacement J Am Coll Cardiol. 2020 Mar, 75 (11_Supplement_1) 1464

58. Costa G, Zappulla P, Barbanti M, Cirasa A, Todaro D, Rapisarda G, Picci A, Platania F, Tosto A, Di Grazia A, Sgroi C, Tamburino C, Calvi V (2019) Pacemaker dependency after transcatheter aortic valve implantation: incidence, predictors and long-term outcomes. EuroIntervention 15(10):875-883. https://doi.org/10.4244/EIJ-D-1801060 (PMID: 31217147)

59. Khounlaboud M, Flécher E, Fournet M, Le Breton H, Donal E, Leclercq C, Mabo P, Leguerrier A, Daubert C (2017) Predictors and prognostic impact of new left bundle branch block after surgical aortic valve replacement. Arch Cardiovasc Dis 110(12):667-675. https://doi.org/10.1016/j.acvd.2017.03.0072017(Epub 2017 Sep 28 PMID: 28964778)

60. Lam KY, Akca F, Verberkmoes NJ, van Dijk C, Claessens A, Soliman Hamad MA, van Straten AHM (2019) Conduction disorders and impact on survival after sutureless aortic valve replacement compared to conventional stented bioprostheses. Eur J Cardiothorac Surg 55(6):1168-1173. https://doi.org/10.1093/ejcts/ezy417 (PMID: 30561575)

61. Chamandi C, Barbanti M, Munoz-Garcia A, Latib A, Nombela-Franco L, Gutiérrez-Ibanez E, Veiga-Fernandez G, Cheema AN, CruzGonzalez I, Serra V, Tamburino C, Mangieri A, Colombo A, JiménezQuevedo P, Elizaga J, Lee DH, Garcia Del Blanco B, Puri R, Côté M, Philippon F, Rodés-Cabau J (2019) Long-term outcomes in patients with new-onset persistent left bundle branch block following TAVR. JACC Cardiovasc Interv 12(12):1175-1184. https://doi.org/10.1016/j. jcin.2019.03.0252019(Epub 2019 May 22 PMID: 31129090)

62. Nazif TM, Chen S, George I, Dizon JM, Hahn RT, Crowley A, Alu MC, Babaliaros V, Thourani VH, Herrmann HC, Smalling RW, Brown DL, Mack MJ, Kapadia S, Makkar R, Webb JG, Leon MB, Kodali SK (2019) New-onset left bundle branch block after transcatheter aortic valve replacement is associated with adverse long-term clinical outcomes in intermediate-risk patients: an analysis from the PARTNER II trial. Eur Heart J 40(27):2218-2227. https:// doi.org/10.1093/eurheartj/ehz227 (PMID: 31505615)

63. Dauerman HL, Reardon MJ, Popma JJ, Little SH, Cavalcante JL, Adams DH, Kleiman NS, Oh JK (2016) Early recovery of left ventricular systolic function after CoreValve transcatheter aortic valve replacement. Circ Cardiovasc Interv 9(6):e003425. https://doi. org/10.1161/CIRCINTERVENTIONS.115.003425 (PMID: 27296201)

64. Klaeboe LG, Brekke PH, Lie ØH, Aaberge L, Haugaa KH, Edvardsen $\mathrm{T}$ (2019) Classical mechanical dyssynchrony is rare in transcatheter aortic valve implantation-induced left bundle branch block. Eur Heart J Cardiovasc Imaging 20(3):271-278. https://doi.org/10.1093/ ehjci/jey127 (PMID: 30247533)

Publisher's Note Springer Nature remains neutral with regard to jurisdictional claims in published maps and institutional affiliations. 